\title{
Examination of Attitudes of Sports Science Faculty Students about Energy Drinks, Sports Drinks and Ergogenic Substances
}

\author{
Burcu Ertas Dolek ${ }^{1} \&$ Tulay Bagci Bosi ${ }^{2}$ \\ ${ }^{1}$ Ankara University, Faculty of Sport Sciences, Department of Coaching Education, Ankara, Turkey \\ ${ }^{2}$ Hacettepe University, Faculty of Medicine, Department of Public Health, Ankara, Turkey \\ Correspondance: Burcu Ertas Dolek, Ankara University Gölbaşı Campus Faculty of Sport Sciences 06830, \\ Ankara, Turkey. E-mail: bdolek@ankara.edu.tr
}

Received: July 29, 2019

Accepted: August 29, 2019

Online Published: September 24,

2019

doi:10.5539/jel.v8n5p241

URL: https://doi.org/10.5539/jel.v8n5p241

\begin{abstract}
Consumption of beverages is not considered adequate by athletes and coaches. The preliminary knowledge of those who are going to study in Sports Sciences Faculties will be very important. All participants were 1st year students. In the study, participants were asked to assess their socio-demographic characteristics and health behaviors, sport habbits, to determine energy drinks (ED), sports drinks (SD) and ergogenic substances (ES) patterns and frequency and consumption purposes, relationship between consumption status. Use a data collection form was prepared to determine the presence or absence of relevant proposals. Total of 101 participants (55 males, $19.2 \pm 1.5$; 46 females, $19.0 \pm 1.2$ years of age), participated in the survey to examine the attitudes of ED, SD and ES. The data were evaluated in the SPSS 21.0. The categorical variablesin the questionnaire were reported as number, percentage, mean and standard deviation. A "chi-square test" and One way ANOVA tests was used. Statistical significance level was accepted as $\mathrm{p}<0,05.52 .5 \%$ of the students stated that energy drinks were beneficial, $57.4 \%$ said sports drinks were beneficial and $61.4 \%$ of the participants said that they did not have an idea about "ergogenic substances". The prevalence of ED usage was $40.0 \%$ for males and $19.5 \%$ for females (p: 0.027 ). While $45.4 \%$ of the males are using the SDs, this rate was found to be $13.0 \%$ in females $(p<0.001)$. Regarding the use of ED, SD and ES, the young population and especially the sports educators in the future should be informed for the public health. As a result of this study, we would like to draw attention to the importance of education for pre-university youth. In recent years, it is important to make new educational arrangements for the developing and changing consumption habits of young people.
\end{abstract}

Keywords: energy drinks, sport drinks, ergogenic substances, university students

\section{Introduction}

Nutrition is the intake and usage of necessary amount of food, needed for human growth, development, a healthy, productive and long life ("WHO | Nutrition", 2017). It is scientifically shown that, without adequate intake, or more than necessary amounts, the growth, development and health is impaired (Dündar, Evliyaoğlu, \& Hatun, 2000). Nutritional habits play an important role in maintaining a healthy, in other words, the quality of life. Proper nutrition and regular physical activity improve mental health as well as physical health (Aşçi, 2003; Prichard \& Tiggemann, 2008). There are many studies on regular physical activity (Bağc1, 2017; Ertaş Dölek, 2017) and nutritional habbits of athletes (Cengizhan, 2018). However, today, with the adoption of an unbalanced diet and a sedentary lifestyle prepare the ground for the emergence of many diseases such as obesity, cardiovascular diseases, diabetes, hypertension, osteoporosis, also leads to depression (Furihata et al., 2018). It is important to keep young people away from bad habits and to implement sports in their daily lives from a young age to keep them physically, mentally and socially healthy in their daily lives (Koçak, 2014). One of the main elements of nutrition is the adequate fluid intake (Dölek, Yildiran, \& Koz, 2014). Water, which has great value for our lives, has many important roles in the body and also our physical fitness. Our body cannot store the fluid necessary for our metabolism. Therefore, we must constantly renew the amount of water lost for our health and body efficiency (Harder, 2009). Our daily physical mobility determines by how much fluid we need. The more we are physically active, the more fluid we lose, the more fluid we need to take (Roh, So, Cho, \& Suh, 2017). Especially individuals dealing with sports should give importance to fluid supplementation in their bodies (Dölek et al., 2014).

One of the components of a healthy diet is also to avoid harmful or known harmful substances. Nowadays, it is 
seen that some of the products consumed in the expectation of health benefits actually cause harm to the body, but it is seen that consumers continue to use these products. The level of knowledge about energy drinks, SDs and ES, which are increasing in consumption, are important among the individuals who are engaged in sports and the trainer candidates. In this study, it is aimed to evaluate the knowledge and attitudes of people who are interested in sports or a profession in sports sciences.

EDs are type of beverages those contain stimulant drugs marketed as mental and (Ishak, Ugochukwu, Bagot, Khalili, \& Zaky, 2012) physical performance enhancers (Committee on Nutrition and the Council on Sports Medicine and Fitness, 2011). Energy drinks have been associated with health risks (Reissig, Strain, \& Griffiths, 2009). Young people's use of EDs just before or during the sport can cause palpitations and heart attacks as a result of dehydration which will develop rapidly due to the effect of caffeine. In addition to fluid loss during exercise, the risk of dehydration increases with the diuretic effect of high-dose caffeine in the content of EDs (Rath, 2012; Sipahi, Sönmez, \& Aydın, 2014).

ESs that increase individual energy use, production or regeneration. As sports sciences term, ergogenic is defined as any method that increases energy use, delays fatigue and improves performance. Nowadays, not only many team doctors and health workers don't have enough knowledge about the benefits and side effects of these additive and supportive products, but also they don't inform the athletes enough about this products (Tokish, Kocher, \& Hawkins, 2004).

\section{Method}

The study is an epidemiological descriptive study. Study population is Faculty of Sport Sciences grade 1th. The sample has not been selected and try to reach the whole population.

101 students (55 males, $19.2 \pm 1.5$ years of age, 46 females, $19.0 \pm 1.2$ years of age) participated as volunteers. A data collection form prepared questionary by the researchers has been distributed and collected on the same day. SPSS 21.0 statistical package program was used to assessment of the data (License Number: 9888978). The categorical variables in the questionnaire form are indicated in the tables as number, percentage, mean and standard deviation. The chi-square test was used to compare the groups. One-way ANOVA test was used to compare the mean values between groups. $\mathrm{P}<0.05$ was accepted as the statistical significance level. All participants gave their informed consent prior to their inclusion in the study.

Limitations: 18 students could not participate in the study for various reasons. However, this deficiency is not thought to affect the results of the study. Considering that all students have been reached; the results of our study will be able to give us information about their approaches to ED, SD, ES for students studying in sports faculties.

\section{Results}

$60.4 \%$ of the participants were 20 years of age and over. $66.3 \%$ of the participants are living with their families, $15.8 \%$ in the dormitory and $17.8 \%$ living alone. $70.3 \%$ of the students participated in the study were smoking and $50.5 \%$ were not consuming alcohol. $36.6 \%$ of the participants stated that they had regular and $63.3 \%$ had irregular sleeping patterns. When they were asked about their nutritional status, $17.8 \%$ stated that they were always adequately, $25.7 \%$ were sometimes adequately eating, $43.6 \%$ were trying to eat enough and $12.9 \%$ were not eating healthy. $31.6 \%$ of the participants had at least 1 chronic disease. The most common disease was anemia with a rate of $23.7 \%$.

Table 1. Participants' sports habits and interest levels

\begin{tabular}{llll}
\hline n: 101 & & $\mathbf{n}$ & $\mathbf{\%}$ \\
\hline Doing sports activities & Yes & 84 & 83.1 \\
& No & 17 & 16.8 \\
Frequency of doing sports & 2 times a week or less & 24 & 23.7 \\
& 3-5 Times per week & 55 & 54.4 \\
Sports type & 6-7 Times per week & 22 & 21.7 \\
& Individual & 46 & 45.5 \\
Suitable material usage according to sports & Team & 55 & 54.4 \\
& Yes, I use it all the time & 76 & 75.2 \\
& I use it partially & 19 & 18.8 \\
Age of starting Sports & No, I don't use & 6 & 5.9 \\
& Under 11 years & 50 & 49.5 \\
Licensed athlete & 11 years and up & 51 & 50.5 \\
& Yes & 61 & 60.4 \\
& No & 40 & 39.6 \\
\hline
\end{tabular}


The findings of participants' sports habbits and their interest levels are presented in Table abow. The majority of the participants appear to be a group of athletes who regularly train and fulfill the requirements of the sport they are interested in, as understood from their statements (Table 1). The findings of BMI values values according to their own declaration and body perceptions given in the Table 2 .

Table 2. BMI values values according to their own declaration and body perceptions

\begin{tabular}{lllllll}
\hline & Male & \multicolumn{3}{c}{ Female } & Total & \\
\cline { 2 - 7 } Calculated BMI & $\mathrm{n}: 55$ & $\%$ & $\mathrm{n}: 46$ & $\%$ & $\mathrm{n}: 101$ & $\%$ \\
Low & 8 & 14.5 & 4 & 8.7 & 12 & 11.9 \\
Normal & 36 & 65.5 & 32 & 69.6 & 68 & 67.3 \\
High & 10 & 18.2 & 8 & 17.4 & 18 & 17.8 \\
Very High & 1 & 1.8 & 2 & 4.3 & 3 & 3.0 \\
Body Perception & & & & & & \\
Low & 8 & 14.5 & 8 & 17.4 & 16 & 15.8 \\
Normal & 39 & 70.9 & 28 & 60.9 & 67 & 66.3 \\
High - Very High & 4 & 7.3 & 7 & 15.2 & 11 & 10.9 \\
No Idea & 5 & 9.1 & 2 & 4.3 & 7 & 6.9 \\
\hline
\end{tabular}

Table 3. Participants' opinions on EDs, SDs and ESs

\begin{tabular}{lllllll}
\hline Participants' Opinions (n: 101) & Useful & \multicolumn{3}{c}{ Harmful } & \multicolumn{2}{c}{ No Idea } \\
\cline { 2 - 7 } & $\mathrm{n}$ & $\%$ & $\mathrm{n}$ & $\%$ & $\mathrm{n}$ & $\%$ \\
EDs & 53 & 52.4 & 27 & 26.7 & 21 & 20.7 \\
SDs & 58 & 57.4 & 19 & 18.8 & 24 & 23.7 \\
ESs & 23 & 22.7 & 16 & 15.8 & 62 & 61.3 \\
\hline
\end{tabular}

When asked about their opinions about EDs, 52.4\% stated that they found it useful, $26.7 \%$ found it harmful and $20.7 \%$ stated that they did not have any information about their content. Then asked about their opinions about SDs, $57.4 \%$ stated that they found it useful, $18.8 \%$ found it harmful and $23.7 \%$ stated that they did not have any information about their content. When asked about their opinions about ESs, $22.7 \%$ stated that they found it useful, $15.8 \%$ found it harmful and $61.3 \%$ stated that they did not have any information about their content (Table 3.)

Table 4. ED, SD and ESs usage by gender and to professional/licensed atlete status

\begin{tabular}{|c|c|c|c|c|c|c|c|c|c|}
\hline & & \multicolumn{4}{|c|}{ Gender } & \multicolumn{4}{|c|}{ Professional/Licensed Athlete } \\
\hline & & \multicolumn{2}{|c|}{ Male (n:55) } & \multicolumn{2}{|c|}{ Female (n:46) } & \multicolumn{2}{|c|}{ Yes } & \multicolumn{2}{|l|}{ No } \\
\hline & & $\mathrm{n}$ & $\%$ & $\mathrm{n}$ & $\%$ & $\mathrm{n}$ & $\%$ & $\mathrm{n}$ & $\%$ \\
\hline \multirow[t]{2}{*}{ ED } & Using & 22 & 40.0 & 9 & 19.5 & 28 & 45.9 & 14 & 35.0 \\
\hline & Not using & 33 & 60.0 & 37 & 80.4 & 33 & 54.1 & 26 & 65.0 \\
\hline \multicolumn{2}{|c|}{ Chi-Square: 4.917} & \multicolumn{4}{|c|}{ p: $\mathbf{0 . 0 2 7}$} & \multicolumn{4}{|c|}{ Chi Square: 2.903 p: 0.088} \\
\hline \multirow[t]{2}{*}{ SD } & Using & 25 & 45.4 & 6 & 13.0 & 25 & 40.9 & 11 & 27.5 \\
\hline & Not using & 30 & 54.5 & 40 & 86.9 & 36 & 59.0 & 29 & 72.5 \\
\hline \multicolumn{2}{|c|}{ Chi Square: 12.370} & \multicolumn{4}{|c|}{$\mathrm{p}:<0.001$} & \multicolumn{4}{|c|}{ Chi Square: 3.942 p: 0.047} \\
\hline \multirow[t]{2}{*}{ ES } & Using & 17 & 30.9 & 8 & 17.3 & 20 & 32.7 & 10 & 25.0 \\
\hline & Not using & 38 & 69.0 & 38 & 82.6 & 41 & 67.2 & 30 & 75.0 \\
\hline \multicolumn{2}{|c|}{ Chi-Square: $\mathbf{2 . 6 3 0}$} & \multicolumn{4}{|c|}{ p: 0.105} & \multicolumn{4}{|c|}{ Chi Square: 2.769 p: 0.096} \\
\hline
\end{tabular}

Considering ED, SD and ES usage by gender, it is seen that male participants are more commonly using these products than female participants. $40.0 \%$ of male subjects are using EDs, while this rate is $19.5 \%$ for females (p: 0.027). The prevalence of use of SDs was $45.4 \%$ in males and $13.0 \%$ in females (p: $<0.001)$. In ES consumption, $30.9 \%$ of males and $17.3 \%$ of females stated that they are using these products (p: 0.105 ). Regarding ergoogenic substance consumption, iti is found that $32.7 \%$ of professional or licensed athletes are using these products where $67.2 \%$ of them are not using and $25.0 \%$ of those who are not engaging any sports did not use these products where $75.0 \%$ of them are not using. Although EDs and ES consumption were more common in professional/licensed athletes, no statistically significant difference was found (Table 4). No significant relationship was found between age of starting sports and usage of EDs and ES. Who has been started sports around 10 years old using SDs more than starded sports older then 10 years old $(\mathrm{p}<0.05) .51 .8 \%$ of all the participants use at least one of these products and $48.5 \%$ of them are not using any products. While $63.4 \%$ of 
those using at least one of the three products recommended, $26.5 \%$ of those who did not recommend it and those who use it suggested more and the difference between them was statistically significant $(p<0.05)$. Also; $62.3 \%$ of the participants did not agree with the idea that EDs, $45.5 \%$ of them that SDs, and $41.5 \%$ of them that the ESs affect our health positively. $27.7 \%$ of the participants stated that EDs were addictive, $47.5 \%$ of them stated that ESs contributed to the muscle development of and $35.6 \%$ stated that SDs are harmful to human metabolism.

\section{Discussion}

The male/female ratio of the participants is $55.4 \% / 45.5 \%$ respectively. This makes the study more valuable and valid. Because the study is it applied only to the $1^{\text {st }}$ grade students of the Faculty of Sport Sciences.

$29.7 \%$ of the students participated in the study stated that they are using cigarettes. According to 2016 data from Turkish Statistical Institute (TSI) smoking rate in Turkey is 26.5 percent. $50.5 \%$ of the participants stated that they are consuming alcoholic beverages. Considering that $29.7 \%$ of the participants are smoking, it can be said that it is higher than the average of Turkey. Dinç et al. (2017) examined the nutritional habits of individuals who regularly exercise sports, and showed that $81.2 \%$ of the participants had their breakfast, $92.2 \%$ had their lunch and $97.4 \%$ had their dinner (Dinç, Gökmen, \& Ergin, 2017). Individuals participating in our study may be considered to need support for the importance of nutrition and eating habits.

The result of the BMI calculated according to their declaration $67.3 \%$ of them normal, $2.9 \%$ of them obese. The frequency of obesity in the world is increasing. According to World Health Organization 2016 data, 18.0\% of children and adolescents aged between 5 and 19 years are obese, and according to the same data, this rate was found to be $11.5 \%$ in 2016 for Turkey. The obesity rate in adults over 18 years of age is $39.0 \%$, while this rate is $32.10 \%$ in Turkey. The implementation of the Healthy Nutrition and Mobile Life Program in progress should continue. It is known that doing sports is very important in terms of prevention of obesity, and weight loss and we have a very important role in primary care which is one of the most important issues of public health. For this reason, we should increase the awareness of sports in the whole society, especially in youth generation, and integrate the sport into our lives. This kind of health policy will ensure that millions of dollars of money will remain in the safe of the state each year and reduce overall health expenses (Ertaş Dölek, 2017).

$40.0 \%$ of the male and $19.5 \%$ of the female use EDs, $45.5 \%$ of the male and $13.1 \%$ of the female use SDs, and $30.9 \%$ male and $17.4 \%$ of female use ESs. As we found in our study, the rate of use among the university students is higher in male (Reid \& Gentius, 2018). In the study conducted on 194 university students, it was determined that $6.7 \%$ of the participants consumed EDs and $5.2 \%$ of them use SDs regularly. $90.2 \%$ of the participants do not know the difference between the concepts of EDs and SDs (Kalkan, Pehlivan, Öztürk, \& Ersoy, 2018). 60.4\% of the do sports as professionally/licensed athlete. In the professional/licensed athlete group, use ED, SD and ES respectly $45.9 \%, 40.9 \%$ and $32.7 \%$. The study conducted in 2017 , to identify the relationships between energy drink consumption and nutrition knowledge, with 194 student-athletes, most participants were aged 18-21 years $(91.8 \%)$ and did not consumeenergy drinks (85.5\%). They also found; the majority of users (64\%) felt that they benefited from consuming energy drinks (Hardy, Kliemann, Evansen, \& Brand, 2017). In similar studies, 35.0\% of individuals used ED in the young age group before the week and $12.0 \%$ used them for 4 and more a week (Utter, Denny, Teevale, \& Sheridan, 2018). In the study of 1255 student participated; out of 1255 participants, 245 reported using EDs. Out of a total 1255 students, 903 (72\%) were from medical and 352 (28\%) from nonmedical colleges of the university (Alabbad et al., 2019). 159 people took part in the other study; 63.3\% confirmed their use of various types of substance, including sports supplements and pharmaceutical product (Dominicis et al., 2017). In another study conducted on 449 university students, it was determined that the most frequently reported reasons for ED consumption were $90.3 \%$ lack of energy and $87.0 \%$ sleep disability, also it was determined that EDs consumption and difficulty for consumption were changing according to the consumers' demographic characteristics (McGaughey, Senkowski, Taylor, Branscum, \& Cheney, 2018).

Endorsements by elite athletes and claims of hydration benefits with little thought to the types and amount of activity that warrant SD use lead to the perception that SDs are healthy. A study from the Yale University Rudd Center for Food Policy and Obesity confirms this idea, finding that more than 1 in 4 American parents believe that SDs are healthy for children (Harris et al., 2014). In our study, $36.5 \%$ of the participants do not recommend such products to the others when they are asked. $52.4 \%$ of the participants think the EDs as beneficial, and this shows that the incentive and false propaganda in the market is really working.

SD consumption contributes to the weight-related conditions on the rise in adolescent population. Clear messaging should be provided about the appropriate use of SDs and the potential health consequences of improper consumption (White, 2019). Compared with energy, SDs and ESs, young people have less information about ESs. It is also noteworthy that those who are aware of the ministry approving EDs, SDs and ESs are in the 
minority. Especially such non-essential foods, should be prevented from taking place in the market so quickly. An awareness should be given to the society and the unconscious use of supplementary nutrients should be prevented with the trainings to be carried out.

When the use of EDs, SDs and ESs according to gender is evaluated, it is seen that the usage of male participants is more common than female participants. Similar results were found in a study conducted with the Saudi university students (Alabbad et al., 2019). The prevalence of ED usage was $40.0 \%$ for males and $19.5 \%$ for females (p: $0.027)$. While $45.4 \%$ of the males are using the SDs, this rate was found to be $13.0 \%$ in females $(\mathrm{p}<0.001)$. There was a difference in the consumption of EDs according to the gender in the youths aged 18-24 (Pettit \& Debarr, 2011). Both sexes should be informed in terms of potential health risks.

The SDs are more commonly consumed by professional/licensed athletes. $40.9 \%$ of the participants' use SDs, frequency of the professional sports male/female is $27.5 \%$ (p: 0.047). Thus, use of SDs has become a part of professional sports life. No significant relationship was found between age of onset of sports and use of EDs and ESs. It was found that the SDs consumers started sports at an early age (p: 0.018).

\section{Conclusion}

These data showed that, efforts should be made to encourage people to participate in sports to create a healthy society. Based on the results, the participants do not have much information about the content of such products. In food consumption, our society should be accustomed to look at the contents of the foods they are consume from primary school ages and a more conscious society should be created. Formal education, health policy-nutrition and consumption trainings at young ages should be provided to shape the habits of young people. Regarding the use of $\mathrm{ED}, \mathrm{SD}$ and ES, the young population and especially the sports educators in the future should be informed for the public health.

\section{References}

Alabbad, M., AlMussalam, M., AlMusalmi, A., Alealiwi, M., Alresasy, A., Alyaseen, H., \& Badar, A. (2019). Determinants of energy drinks consumption among the students of a Saudi University. Journal of Family and Community Medicine, 26(1), 36. https://doi.org/10.4103/jfcm.JFCM_42_18

Aşçi, F. H. (2003). The effects of physical fitness training on trait anxiety and physical self-concept of female university students. Psychology of Sport and Exercise, 4(3), 255-264. https://doi.org/10.1016/S1469-0292(02)00009-2

Bağcı, E. (2017). A study on habits of using fitness centre $<p>$ Fitness merkezi kullanım alışkanlıkları üzerine bir araştırma. Journal of Human Sciences, 14(3). https://doi.org/10.14687/jhs.v14i3.4617

Cengizhan, P. A. (2018). Knowledge and Use of Dietary Supplement Products by Deaf Athletes. Journal of Education and Training Studies, 6(6), 111. https://doi.org/10.11114/jets.v6i6.3231

Committee on Nutrition and the Council on Sports Medicine and Fitness. (2011). Clinical Report-Sports Drinks and Energy Drinks for Children and Adolescents: Are They Appropriate? Pediatrics, 127. https://doi.org/10.1542/peds.2011-0965

Dinç, N., Gökmen, M. H., \& Ergin, E. (2017). Düzenli Egzersiz Yapan Bireylerin Beslenme Alışkanlıklarının İncelenmesi. Ulusal Spor Bilimleri Dergisi, 1(1), 43-53. https://doi.org/10.30769/usbd.313945

Dominicis, E. D. E., Cammarano, A., Schiattarella, R., Legale, M., Tor, R., \& Biomedici, D. (2017). Conoscenze e percezioni sull'utilizzo delle sostanze per l'aumento della performance. Edizioni Minerva Medica, 137(3), 57-64. https://doi.org/10.23736/S0026-4849.17.01767-9

Dündar, Y., Evliyaoğlu, O., \& Hatun, Ş. (2000). Okul çocuklarında boy kısalığı ve obesite: ihmal edilen bir sorun. Turkiye Klinikleri Journal of Pediatrics, 9(1), 19-22.

Ertaş Dölek, B. (2017). Determination of exercise behaviors of healthy adult individuals over 18 years of age $<\mathrm{p}>18$ yaş üzeri sağlıklı yetişkin bireylerin, egzersiz alışkanlıklarının incelenmesi. Journal of Human Sciences, 14(2), 1924. https://doi.org/10.14687/jhs.v14i2.4525

Ertaş Dölek, B., Yildiran, İ., \& Koz, M. (2014). Yüzmenin Neden Olduğu Vücut Sıvı Dengesindeki Değişimlerin Yüzme Performansına Etkisi. Ankara Üniversitesi Spor Bilimleri Fakültesi, Spormetre Dergisi, 12(2), 89104. https://doi.org/10.1501/Sporm_0000000257

Furihata, R., Konno, C., Suzuki, M., Takahashi, S., Kaneita, Y., Ohida, T., \& Uchiyama, M. (2018). Unhealthy lifestyle factors and depressive symptoms: A Japanese general adult population survey. Journal of Affective Disorders, 234(March), 156-161. https://doi.org/10.1016/j.jad.2018.02.093 
Harder, C. (2009). Position of the American Dietetic Association, Dietitians of Canada, and the American College of Sports Medicine: Nutrition and Athletic Performance. Journal of the American Dietetic Association, 109(3), 509-527. https://doi.org/10.1016/j.jada.2009.01.005

Hardy, R., Kliemann, N., Evansen, T., \& Brand, J. (2017). Relationship Between Energy Drink Consumption and Nutrition Knowledge in Student-Athletes. Journal of Nutrition Education and Behavior, 49(1), 19-26. https://doi.org/10.1016/j.jneb.2016.08.008

Harris, J. L., Schwartz, M. B., Lodolce, M., Munsell, C., Fleming-Milici, F., Elsey, J., ... Dembek, C. (2014). Sugary drink F.A.C.T.S. Rudd Center for Food Policy and Obesity. Retrieved from http://www.sugarydrinkfacts.org/resources/sugarydrinkfacts_report.pdf

Ishak, W. W., Ugochukwu, C., Bagot, K., Khalili, D., \& Zaky, C. (2012). Energy drinks: psychological effects and impact on well-being and quality of life-a literature review. Innovations in Clinical Neuroscience, 9(1), 25-34. Retrieved from http://www.ncbi.nlm.nih.gov/pubmed/22347688

Kalkan, I., Pehlivan, M., Öztürk, S. A., \& Ersoy, G. (2018). Energy Drinks Among University Students: A Pilot Study in Turkey. BLDE University Journal of Health Sciences, 3(1), 18-23. https://doi.org/10.4103/bjhs.bjhs_4_18

Koçak, F. (2014). Üniversite Öğrencilerinin Spora Yönelik Tutumlari: Bir Ölçek Geliştirme Çalışması. Ankara Univ Spor Bil Fak, 12(1), 59-69. https://doi.org/10.1501/Sporm_0000000254

McGaughey, A., Senkowski, V., Taylor, L., Branscum, P., \& Cheney, M. (2018). Relationship Between Energy Drink Consumption and Daily Hassles Among College Students. American Journal of Health Education, 49(3), 190-197. https://doi.org/10.1080/19325037.2018.1448731

Pettit, M. L., \& Debarr, K. A. (2011). Perceived stress, energy drink consumption, and academic performance among college students. Journal of American College Health, 59(5), 335-341. https://doi.org/10.1080/07448481.2010.510163

Prichard, I., \& Tiggemann, M. (2008). Relations among exercise type, self-objectification, and body image in the fitness centre environment: The role of reasons for exercise. Psychology of Sport and Exercise, 9(6), 855866. https://doi.org/10.1016/j.psychsport.2007.10.005

Rath, M. (2012). Energy drinks: What is all the hype? The dangers of energy drink consumption. Journal of the American Academy of Nurse Practitioners, 24(2), 70-76. https://doi.org/10.1111/j.1745-7599.2011.00689.x

Reid, S. D., \& Gentius, J. (2018). Intensity of energy drink use plus alcohol predict risky health behaviours among university students in the Caribbean. International Journal of Environmental Research and Public Health, 15(11). https://doi.org/10.3390/ijerph15112429

Reissig, C. J., Strain, E. C., \& Griffiths, R. R. (2009). Caffeinated energy drinks-A growing problem. Drug and Alcohol Dependence, 99(1-3), 1-10. https://doi.org/10.1016/j.drugalcdep.2008.08.001

Roh, H.-T., So, W.-Y., Cho, S.-Y., \& Suh, S.-H. (2017). Effects of Fluid Ingestion on Brain-Derived Neurotrophic Factor and Cognition During Exercise in the Heat. Journal of Human Kinetics, 58(1), 73-86. https://doi.org/10.1515/hukin-2017-0074

Sipahi, H., Sönmez, İ., \& Aydın, A. (2014). Energy Drink and Effects on Human Health. Rewiev, Turkiye Klinikleri J Pharm Sci., 3(1), 39-46.

Tokish, J. M., Kocher, M. S., \& Hawkins, R. J. (2004). Ergogenic aids: A review of basic science, performance, side effects, and status in sports. American Journal of Sports Medicine, 32(6), 1543-1553. https://doi.org/10.1177/0363546504268041

Utter, J., Denny, S., Teevale, T., \& Sheridan, J. (2018). Energy drink consumption among New Zealand adolescents: Associations with mental health, health risk behaviours and body size. Journal of Paediatrics and Child Health, 54(3), 279-283. https://doi.org/10.1111/jpc.13708

White, N. D. (2019). Approaches to Reduce Sports Drink Consumption Among Adolescents. American Journal of Lifestyle Medicine, 13(2), 145-147. https://doi.org/10.1177/1559827618815808

WHO | Nutrition. (2017). WHO. Retrieved from http://www.who.int/topics/nutrition/en/ 


\section{Copyrights}

Copyright for this article is retained by the author, with first publication rights granted to the journal.

This is an open-access article distributed under the terms and conditions of the Creative Commons Attribution license (http://creativecommons.org/licenses/by/4.0/). 